\title{
Proceeding
}

Performance Analysis Workshop, 2 - 5 April 2013, Alicante, Spain

\section{The use of hyperoxia as a way to accelerate recovery after a karate and judo match}

\author{
MARTIN PUPIŠ, MIROSLAV SLIŽIK, PAVOL BARTÍK \\ Department of Physical Education and Sport, Faculty of Humanities, Matej Bel University in Banská Bystrica, \\ Slovakia
}

\begin{abstract}
Pupiš M, Sližik M, Bartík P. The use of hyperoxia as a way to accelerate recovery after a karate and judo match. J. Hum. Sport Exerc. Vol. 8, No. Proc3, pp. S608-S614, 2013. The research study is concerned with the use of hyperoxia (an abnormally increased supply or concentration of oxygen) as a possible way to accelerate recovery time after anaerobic load in karate and judo. The study sample consisted of 23 top athletes (14 karatekas, 9 judokas) aged 22 to 29 . All these athletes inhaled a hyperoxic gas mixture (containing $95 \pm 4 \%$ of oxygen in the inhaled air) or a placebo (air) from an oxygen concentrator before and after the match. Lactate level was measured in the third and 10th minute after the match. Following the match before which the athletes had inhaled the concentrated oxygen, the average lactate level was 10.44 (SD 2.76) $\mathrm{mmol} / \mathrm{L}$. On the other hand, the lactate level after the match before which they had inhaled placebo equalled 10.43 (SD 2.92) mmol/L. The difference between the results represents $0.0009 \%$ which is considered not to be of any statistically significance. A statistically significant difference $(p<0.05)$ was recorded after three-minute recovery - following the inhalation of the hyperoxic gas mixture the average lactate level reached 8.53 (SD 2.82) mmol/L. This represented a decrease of $18.12 \%$ while after inhaling the placebo the average lactate level equalled 9.06 (SD 2.98) $\mathrm{mmol} / \mathrm{L}$ (a $13.4 \%$ decrease). Following the ten-minute recovery we observed the average lactate level of 6.65 (SD 2.31) $\mathrm{mmol} / \mathrm{L}$ after the inhalation of the hyperoxic gas mixture (a $36.3 \%$ decrease compared to the values before the match). The average lactate level measured after the inhalation of placebo represented 7.73 (SD 2.39) $\mathrm{mmol} / \mathrm{L}$ (a 25.86\% decrease). We ascertained the statistical significance of the difference between the dynamics of lactate metabolism after the inhalation of the hyperoxic gas mixture and after inhaling air $(p<0.05)$. The inhalation of hyperoxic gas mixture before a match does not have a statistically significant effect on the lactate level after the load. However, the inhalation of hyperoxic gas mixture does significantly affect the dynamics of lactate metabolism in the third and 10th minute of the recovery time, based on the $p<0.05$ level of statistical significance. Based on this result, we consider the inhalation of hyperoxic gas mixture an appropriate way to accelerate recovery time after a judo and karate match. Key words: HYPEROXIA, MATCH LOAD, RECOVERY TIME, JUDO, KARATE
\end{abstract}

Corresponding author. Department of Physical Education and Sport. Faculty of Humanities, Matej Bel University. Tajovského street 40. 97401 Banská Bystrica. Slovakia. Phone number: 0042148 4467529. mobile: 00421911245572

E-mail: pavol.bartik@umb.sk

Performance Analysis Workshop, 2 - 5 April 2013, Alicante, Spain

JOURNAL OF HUMAN SPORT \& EXERCISE ISSN 1988-5202

(c) Faculty of Education. University of Alicante

doi:10.4100/jhse.2013.8.Proc3.06

VOLUME 8 | Proc3 | 2013 | S608 


\section{INTRODUCTION}

In general, a lack of oxygen negatively affects performance and increases recovery time. Regarding this, the question arises whether the inverse is also true. The reason for this may be the increased oxygen saturation of blood and tissue and the anaerobiosis of the working muscles, which accelerates subsequent recovery and return to the baseline levels (Haseler et al., 1999, Nummela et al., 2002). The positive effect of hyperoxia decreases with the longer duration of the load since our organism cannot create oxygen reserves. This is caused by the limited capacity of the tissue to produce non-physiologically increased amounts of oxygen (Robbins et al., 1992). Yamaji \& Shephard (1985) stated that the effect of concentrated oxygen inhalation lasts from tens of seconds to several minutes. Therefore, we can presume that in hyperoxic conditions more effective lactate utilization will take place. Heigenhauser et al. (2006) confirmed a significant relationship between lactate accumulation and the oxygen concentration of inhaled air. Nummela et al. (2006) affirmed a significant relationship between the oxygen saturation of blood and the concentration of oxygen in inhaled air.

As a part of the VEGA 1/1175/12 and 1/0927/12 grant programmes, we decided to monitor the impact of hyperoxia on the acceleration of recovery time after judo and karate matches, since these sports comprise a relatively short-term anaerobic load.

We know that lactic acid $(\mathrm{C} 3 \mathrm{H} 6 \mathrm{O} 3)$ is produced during intensive load. It is immediately dissociated into lactate (C3H5O3), the lactate anion ( $\mathrm{La-}$ ) and hydrogen cation $(\mathrm{H}+)$. This causes organism acidosis during load. The human organism enables the resynthesis of lactate into glycogen. Havličková et al. (2008) confirms that an adequate supply of oxygen must be ensured during and after anaerobic exercise to enable energy resynthesis and the suppression of acidosis. In sport training, the balance between quantity and quality is of great importance. While maintaining quality, the quantity of the exercise may cause fatigue associated with muscle weakness. The causes of muscle weakness are complex. The important factor associated with short-term intensive load is the phosphocreatine level, which significantly decreases after crossing the individual's critical threshold, while at the same time the inorganic phosphate concentration increases (Jones et al., 2008). Inorganic phosphate can affect subsequent muscle contraction by entering the sarcoplasmic reticulum and excreting calcium cation (Allen et al., 2008). Creatine is phosphorylated to high-energy phosphocreatine solely in aerobic conditions (Haseler et al., 1999), while at the same time inorganic phosphate is reduced. In this way, hyperoxia can accelerate recovery.

Judo and sport karate are both martial and power-speed sports in which the intensity of the load changes in irregular intervals from medium to maximum. In a single judo duel (match), the duration of the load is 5 minutes in men and up to 4 minutes in women. In a karate duel the duration of the load equals 3 minutes in men (4 minutes in the case of a medal match) and 2 minutes in women ( 3 minutes in the case of a medal match). Such loads are managed by the metabolic energy system in the form of ATP-CP, consisting of anaerobic glycolysis and aerobic phosphorylation. According to Zemková et al. (2006), the maximum heart rate in men performing karate ranges from 182 to $198 \mathrm{bpm}$, and the average lactate concentration following performance in training conditions ranges from 8.4 up to $16.7 \mathrm{mmol} / \mathrm{L}$. The adaptation to aerobic and anaerobic load, which is determined by the recovery time between the loads, is one of the key factors affecting individual performance in speed-power combat sports, including judo and karate. 


\section{MATERIAL AND METHODS}

The study sample consisted of 23 athletes (14 karatekas, 9 judokas) aged approximately 22 . The sample was composed of top athletes, members of the national teams of Slovakia. All monitored athletes went through the match load, before and after which they inhaled air from the oxygen concentrator.

Each of the monitored athletes took part in 4 to 6 matches (kumite/randori) against different opponents. The length of the karate match (kumite) was 3 minutes and the judo match (randori) lasted for 5 minutes. All matches were conducted in training conditions without interruption by the referee of the event. After one of the competitors successfully scored, the model match continued until the total duration of a single match was reached. The recovery time between the matches was established as a model with respect to a real competition load from 3 to 10 minutes. Each of them entered four matches. After two of them they were given the placebo to inhale, and after two more they were given the concentrated oxygen ( $95 \pm 4 \%$ oxygen in the inhaled air). We monitored the lactate level after the match load and also in the third and the tenth minute after the match ended.

\section{RESULTS}

If our results are to be objective, it is important to know the input values of lactate levels prior to the load. Our findings show that all monitored athletes displayed input values corresponding to the baseline, i.e. 1.6 $\mathrm{mmol} / \mathrm{L}$. After the standard warm-up they took part in the match.

Once the match was over, the average lactate level in the athletes who had inhaled the concentrated oxygen was 10.44 (SD 2.76) $\mathrm{mmol} / \mathrm{L}$. On the other hand, following the match played by the athletes who had inhaled the placebo the lactate level was 10.43 (SD 2.92) $\mathrm{mmol} / \mathrm{L}$. The difference between the results is $0.0009 \%$, which is not considered to be of any statistical significance. However, in the first minute the athletes who had inhaled the hyperoxic gas mixtures had lower heart rates $(-5.6 \mathrm{bpm})$, which constitutes a $p<0.05$ level of statistical significance. Nevertheless, after the first minute of load both of these values equalized (Figure1).

A statistically significant difference $(p<0.05)$ was recorded only after three minutes of recovery, when the athletes who had inhaled the hyperoxic gas mixture exhibited an average lactate level of 8.53 (SD 2.82) $\mathrm{mmol} / \mathrm{L}$, which represented an $18.12 \%$ decrease. After inhaling the placebo, the average lactate level equalled 9.06 (SD 2.98) $\mathrm{mmol} / \mathrm{L}$ (a 13.4\% decrease). We also recorded a statistically significant decrease of heart rate after the first minute of recovery $(-8.1 \mathrm{bpm})$ compared to the recovery with the use of the placebo. In the 10th minute of resting, we recorded average lactate levels of 6.65 (SD 2.31) mmol/L following the inhalation of the hyperoxic gas mixture. This represents a $36.3 \%$ decrease compared to the figures immediately after the match. The average lactate level measured after the inhalation of the placebo was $7.73 \mathrm{mmol} / \mathrm{L}$ (SD 2.39), i.e. a $25.86 \%$ decrease. We determined a statistical significance in the difference between the dynamics of lactate metabolism after the inhalation of the hyperoxic gas mixture and after inhaling air $(p<0.05)$. The average heart rate in the third to the tenth minute was on average lower by $2.8 \mathrm{bpm}$, which is not statistically significant. 


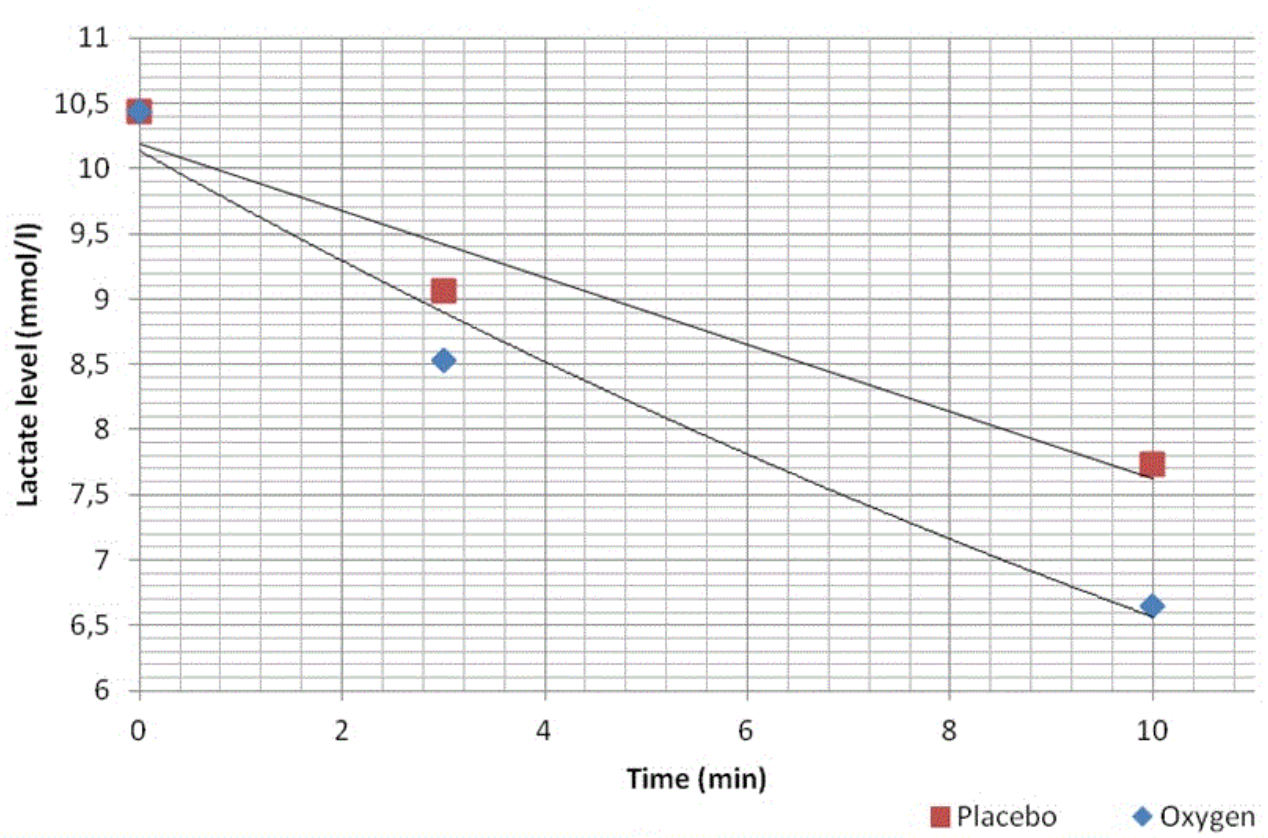

Figure 1. Comparison of the dynamics of lactate metabolism after inhalation of hyperoxic gas mixture and after inhaling placebo

The adaptation to the alternation of aerobic and anaerobic loads is one of the key factors affecting performance in judo and karate. It is determined by the speed of regeneration and recovery between the loads. The quality and recovery time between individual matches significantly influences the performance in the following match. This is directly related to the availability of energy in the form of ATP-CP (anaerobic glycolysis and aerobic phosphorylation) as well as the functional capability of the organism to provide speed-strength performance. The energy and biochemical intensity of the psychological load (emotional instability, temperament) is an integral part of the particular demands of the two martial sports. The functionality of cognitive and sensorimotor skills such as reaction time, disjunctive reaction capabilities and continuous attention are among the factors determining sport performance in judo and karate. Not only do the speed and efficiency of recovery time after a match have a significant effect the physiological state and health of the body, but they also affect the optimal function of mental regulatory processes and mental activation. With regard to the organization of top sport events according to international rules, the competitive load during an elimination tournament (bracket system) is of a cumulative nature, because the time for regeneration between matches shortens. The regeneration time before medal matches usually lasts from 3 hours to 2 days, depending on the nature of the tournament. The most important part of the competition is elimination, in which it is decided whether the athlete continues in the competition or not. In terms of regeneration and recovery, we have to take into account that the athlete will face a more difficult opponent in the next round. It is important to ensure that s/he is supplied with the maximum amount of energy. In the stage of recovery, lactate resynthesizes into glucose (glycogen). Our research indicates that the inhalation of hyperoxic gas mixtures accelerates the creation of energy reserves after the intense load. Consequently, it leads to the activity of buffered systems and suppression of acidosis. In terms of sport performance in karate and judo, the suppression of acidosis and energy deficit are the most limiting factors. 


\section{DISCUSSION}

The inhalation of concentrated oxygen (hyperoxia) has been the subject of study since the mid-20th century, with numerous authors investigating the effects of hyperoxia on the human organism (Bannister \& Cunningham, 1954; Welch, 1982, 1987; Snell et al., 1986; Plet et al., 1992; Knight et al.,1996; Takafumi \& Yasukouchi, 1997; Morris et al., 2000; Harms et al., 2000; Peltonen et al., 2001; Wilber et al., 2004, 2003; Kay et al., 2008; Suchý et al., 2008, 2010a, b; Pupiš et al., 2009, 2010). The positive impact of hyperoxia on the organisms of athletes has been largely confirmed by these authors. A single or repeated short-term application of concentrated oxygen or hyperoxic gas mixtures temporarily increases the oxygen saturation of blood and tissue, which can be used to accelerate recovery after intermittent loads (Nummela et al., 2002, Suchý et al., 2008, 2010a, b). However, there have been some research studies which did not confirm the positive impact of oxygen inhalation on the human organism. Robbins et al. (1992) and YamajiShephard (1985) did not observe any positive effects of oxygen inhalation on the human organism, in the cases of short-term submaximal and maximum loads. Máček et al (2011) questioned pure oxygen inhalation and stated that hyperoxic gas mixtures can increase the oxygen level in blood by $1 \mathrm{ml}$ per 100 $\mathrm{ml}$. Nevertheless, if one considers that $100 \mathrm{ml}$ of blood contains about $20 \mathrm{ml}$ of oxygen, this represents an increase of up to $5 \%$. On the other hand, Máček et al (2011) also acknowledged that redressing the balance between oxygen and carbon dioxide takes 12 hours after the load, while the removal of excess lactate also takes a few hours.

\section{CONCLUSIONS}

According to our study, inhalation of hyperoxic gas mixtures is an appropriate method to accelerate the recovery and regeneration time under loads of anaerobic exercises. Our research shows that the inhalation of hyperoxic mixture before a match does not have a statistically significant impact on the lactate level after the load. The inhalation of the hyperoxic gas mixture significantly $(p<0.05)$ affected the dynamics of lactate metabolism in the 3rd and 10th minute of recovery. Based on our results, the inhalation of a hyperoxic gas mixture can be said to be an appropriate way to accelerate recovery time after a judo or karate match. The effect of a hyperoxic gas mixture is stronger when one inhales it for a longer time. According to our results, the recovery and restoration of energy stores after inhaling a hyperoxic gas mixture is approximately one-third faster than without the use of hyperoxic gas mixtures.

\section{REFERENCES}

1. ALLEN DG, LAMB GD, WERBALD H. Impaired calcium release during fatigue. Journal of Applied Physiology. 2008; 104:296-305.

2. BANNISTER RG, CUNNINGHAM DJC. The effects on the respiration and performance during exercise of addingoxygen to theinspiredair. J. Physiol.1954; 125:118-137.

3. HARMS C, MCCLARAN S, NICKELE G, PEGELOW D, NELSON W, DEMPSEY J. Effect of exercise-induced arterial 02 desaturation on V02max in women. Medicine and Science in Sports and Exrecise. 2000; 32:1101-8.

4. HASELER LJ, HOGAN MC, RICHARDSON RS. Skeletal muscle phosphocreatine recovery in exercise-trained humans is dependent on 02 availability. Journal of Applied Physiology. 1999; 86:2012-2018.

5. HAVLÍČKOVÁ L, DLOUHÁ R, VRÁNOVÁ J, BARTU゚ÑKOVÁ S, MELICHNA J, ŠRÁMEK P, VODIČKA P. Fyziologie tělesné záteže I. (obecná část). Praha : Karolinum. 2008. 
6. HEIGENHAUSER AND LAWRENCE L, SPRIET, TRENT STELLINGWERFF, PAUL J, LEBLANC, MELANIE G, HOLLIDGE, GEORGE JF. Hyperoxiadecreases muscle glycogenolysis, lactate production, and lactate efflux during steady-state exercise. American Journal of Physiology Endocrinology and Metabolism. 2006; 290:1180-1190.

7. JONES AM, WILKERSON DP, DIMENNA F, FULFORD J, POOLE D. Muscle metabolic response to exercise above and below "the critical power" assessedusing31 P-MRS. American Journal of Physiology, 2008; 294: 585-593.

8. KAY B, STANNARD SR, MORTON H. Hyperoxia during recovery improve speak power during repeated Wingate cycle performance. Brasil Biomot. 2008; 2:92-100.

9. KNIGHT D, POOLE D, HOGAN M, BEBOUT D, WAGNER P. Effect of inspired oxygen concentration on leg lactate release during incremental exercise. Journal of Applied Physiology. 1996; 81:246-51.

10. MÁČEK M, RADVANSKÝ J. et al. Fyziologie a klinické aspekty pohybové aktivity. Praha: Galén. 2011, $245 \mathrm{p}$.

11. MORRIS DM, KEARNEY JT, BURKE ER. The effects of breathing supplement aloxygen medicine altitude training on cycling performance. Journal of Science and Medicine in Sport. 2000; 3:165175.

12. NUMMELA A, HAMALAINEN I, RUSKO H. Effect of hyperoxic on metabolic response and recovery in intermittent exercise. Scandinavian Journal of Medicine and Science in Sports. 2002; 12: 309315.

13. PELTONEN J, TIKKANEN H, RUSKO $H$. Cardio respiratory responses to exercise in acute hypoxia, hyperoxia, and normoxia. European Journal of Applied Physiology. 2001; 85:82-8.

14. PLET J. PEDERSEN P. JENSEN F, HANSEN J. Increased working capacity with hyperoxia in humans. European Journal of Applied Physiology. 1992; 65:171-7.

15. PUPIŠ M, ŠTIHEC J, BROĎÁNI J. Vplyv inhalácie 99,5\% kyslíka na organizmus basketbalistov pri anaeróbnom załažení. Exercitatio corpolis - motus-salus. Slovak journal of sports sciences. 2009; 1:80-86.

16. PUPIŠ M, RAKOVIĆ A, SAVANOVIĆ V, STANKOVIĆ S, KOCIĆ M, BERIĆ D. Hyperoxy as a form of anaerobic workload reduction on the elite bakteball players. Acta Kinesiologica. 2010; 4:45-48.

17. ROBBINS MK, GLEESON K, ZWILLICH CW. Effects of oxygen breathing following submaxima and maxima exercise on recovery and performance. Medicine and Science in Sports and Exercise. 1992; $24: 720-725$.

18. SHELL PG, WINTER FD, STRAY-GUNDERSEN J. Does $100 \%$ oxygenaid recovery from exhaustive exercise? Medicine and Science in Sports and Exercise. 1986; 18 (2), Supplement 9.

19. SUCHÝ J, HELLER J, VODIČKA P, PECHA J. Vliv inhalace $99,5 \%$ kyslíku na opakovaný krátkodobý výkon maximální intenzity. Česká kinantropologie. 2008; 12:15-25.

20. SUCHÝ J, HELLER J, VODIČKA P, PECHA J. Možnosti ovlivnění reakční doby a jejich vliv na kvalitu pracovní zátěže u profesionálních ridičú. Acta Universitatis Purkynianae, Studia Valetudinaria: Kvalita života II., UJEP: Ústí nad Labem, 2010a. Pp.194-202.

21. SUCHÝ J, NOVOTNÝ J, TILINGER P. Porovnání vlivu hyperoxie na krátkodobý anaerobní výkon v nižině a vyšší nadmořské výšce. Studia Sportiva. 2010b; 4:17-24.

22. TAKAFUMI M, YASUKOUCHI A. Blood lactate disappearance during breathing hyperoxic gas afte rexercise in two different physical fitness groups - on the workload fixedat $70 \%$ VO2. Applied Human Science: Journal of Physiological Anthropology. 1997; 16: 249-255.

23. WILBER RL, HOLM PL, MORRIS DM, DALLAM GM, CALLAN SD. Effect of FIO2 on Physiological Responses and Cycling Performance at Moderate Altitude. Medicine and Science in Sports and Exercise. 2003; 35:1153-1159. 
24. WILBER RL, HOLM PL, MORRIS DM, DALLAM GM, SUBUDHI AW, MURRAY DM, CALLAN SD. Effect of $\mathrm{FIO} 2$ on oxidative stress during interval training at moderate altitude. Medicine and Science in Sports and Exercise. 2004; 36:1888-1894.

25. YAMAJI K, SHEPHARD RJ. Effect of physical working capacity of breathing 100 percent $\mathrm{O} 2$ during rest or exercise. Journal of Sports Medicine and Physical Fitness. 1985; 25: 238-242.

26. WELCH HG. Hyperoxia and human performance. Medicine and Science in Sports and Exercise. 1982; 14:253-62.

27. WELCH HG. Effects of hypoxia and hyperoxia on human performance. Exercise and Sport Science Reviews. 1987; 15:191-221.

28. ZEMKOVÁ E, SLIŽIK M, LONGA J, MIKLOVIČ, P. Teória a didaktika karate. Bratislava : FTVŠ UK, 2006. $126 \mathrm{p}$. 